\title{
Ketahanan Keluarga Pasangan Menikah yang Bekerja di Luar Negeri (Kajian di Desa Kalirejo, Kecamatan Kalipare, Kabupaten Malang)
}

\author{
Yunita Dwi Pristiani ${ }^{(1)}$, Agus Widodo ${ }^{(2)}$ \\ ${ }^{1,2}$ Prodi PPKn Universitas Nusantara PGRI Kediri \\ Email: 1'yunitadp@unpkediri.ac.id, 22aguswid@unpkediri.ac.id
}

\section{Tersedia Online di \\ http://www.jurnal.unublitar.ac.id/ index.php/briliant}

\section{Sejarah Artikel \\ Diterima pada 14 April 2018 \\ Disetuji pada 9 Mei 2018 \\ Dipublikasikan pada 13 Mei \\ 2018 Hal. 237-244}

\section{Kata Kunci:}

ketahanan keluarga, tki, pasangan menikah,

\section{DOI:}

http://dx.doi.org/10.28926/briliant .v3i2.177

\begin{abstract}
Abstrak: Ketahanan keluarga merupakan pondasi kekuatan bangsa. Kerapuhan ketahanan keluarga yang berujung pada perceraian sering kali terdapat pada pasangan keluarga kelas menengah ke bawah yang menjadi TKI di luar negeri. Hal ini menyebabkan kondisi pendidikan anak-anak yang berasal dari broken home juga tidak kalah mengkhawatirkan. Penelitian ini dilakukan untuk mengkaji ketahanan keluarga pasangan menikah yang menjadi TKI di luar negeri yang berasal dari Desa Kalirejo, Kalipare, Malang. Metode yang digunakan adalah metode deskriptif kualitatif, dengan melakukan wawancara mendalam. Analisis data dilakukan melalui koding. hasil penelitian menunjukkan, banyak aspek yang tidak mendukung ketahanan keluarga para TKI yang bekerja di luar negeri. Yaitu ketahanan hubungan pernikahan yang rapuh, Anak-anak yang tidak terdidik dengan baik di rumah. Kondisi ekonomi yang mayoritas juga tidak jauh berbeda setelah menjadi TKI.
\end{abstract}

Ketahanan bangsa berakar dari kelompok sosial paling kecil yang ada di dalam masyarakat yaitu keluarga. Keluarga menentukan ketahanan suatu bangsa, baik dari segi ketahanan ekonomi, ketahanan budaya, ketahanan pendidikan, ketahanan agama, semua berawal dari satu titik yaitu ketahanan keluarga. Di dalam keluarga terjadi interaksi antar anggotanya yang terus berkembang dan menciptakan kebudayaan dalam masyarakat. setiap individu bersifat kemasyarakatan, terkait dengan hal ini, Muthahhari dalam Handoyo (2013) mengeksplorasi pandangan, bahwa manusia bersifat kemasyarakatan, pandangan ini menunjukkan kehidupan bermasyarakat manusia sama dengan kerekanan seorang pria dan seorang wanita dalam kehidupan berumah tangga dimana masing-masing merupakan bagian dari keseluruhan dan masing-masing berpikir ingin bersatu dengan keseluruhan itu.

Penelitian ini dilakukan atas dasar kekhawatiran yang mendalam terhadap kondisi ketahanan keluarga yang merupakan pondasi ketahanan bangsa, terutama keluarga menengah kebawah. Keutuhan keluarga yang semakin mengkhawatirkan secara tidak langsung mengancam ketahanan bangsa Indonesia. Ihromi (2004), menyatakan sebuah keluarga disebut harmonis apabila seluruh anggota keluarga merasa bahagia yang ditandai oleh berkurangnya ketegangan, kekecewaan, serta puas terhadap seluruh keadaan dan keberadaan dirinya (eksistensi atau aktualisasi diri) yang meliputi aspek fisik, mental, emosi dan sosial seluruh anggota keluarga. Keharmonisan keluarga berkaitan dengan suasana 
hubungan perkawinan yang bahagia dan serasi. Ketidak harmonisan keluarga banyak dijumpai pada keluarga dengan pasangan yang bekerja di luar negeri sebagai tenaga kerja Indonesia, baik laki-laki maupun perempuan. Pasangan yang memilih bekerja diluar negeri didominasi oleh keluarga dengan perekonomian menengah kebawah. Peneliti berasumsi bahwa bekerja di luar negeri dengan tujuan menyelesaiakan masalah, sebenarnya malah dapat memunculkan berbagai masalah baru dalam keluarga atau rumah tangga. Oleh karena itu, sedikit berbeda dari penelitian yang pernah ada sebelumnya yang memfokuskan penelitian pada Perilaku Sosial Keluarga Tenaga Kerja Indonesia yang didalamnya membahas soal gaya hidup, perceraian, kultur, ekonomi, dan Pendidikan, penelitian ini memfokuskan pada kondisi ketahanan keluarga pada pasangan menikah yang bekerja di luar negeri. Ketahanan keluarga tersebut akan diukur melalui tingkat keharmonisan pasangan, kualitas pendidikan anak, dan kondisi perekonomian keluarga pasangan yang bekerja di luar negeri, sekaligus berusaha menemukan solusi efektif yang bisa digunakan sebagai alternatif jalankeluar dari permasalahan ekonomi keluarga selain harus bekerja menjadi TKI di luar negeri .

Tujuan jangka panjang dari penelitian ini adalah agar masyarakat menengah ke bawah khususnya yang berada di Kabupaten Malang tidak menjadikan bekerja ke-luar negeri sebagai pilihan jalan keluar utama penyelesaian permasalahan ekonomi keluarga. Selain itu, penelitian ini juga bertujuan untuk menemukan solusi efektif sebagai jalan alternatif lain untuk mengatasi permasalahan ekonomi keluarga selain bekerja sebagai Tenaga Kerja Indonesia di luar negeri. Berbeda dari penelitian Secara rinci tujuan penelitian ini adalah untuk mengetahui (1) Ketahanan hubungan pernikahan antara pasangan yang bekerja di luar negeri, (2) Kualitas pendidikan dan kebahagiaan anak-anak dari pasangan orang tua yang bekerja di luar negeri, (3) Ketahanan ekonomi keluarga dari pasangan yang bekerja di luar negeri, dan (4) Menemukan solusi efektif yang bisa digunakan sebagai alternatif jalan keluar dari permasalahan ekonomi keluarga selain harus bekerja menjadi TKI di luar negeri.

\section{METODE}

Jenis atau model penelitian ini adalah penelitian kualitatif. Penelitian kualitatif adalah penelitian yang bersifat deskriptif dan cenderung menggunakan analisis dengan pendekatan induktif. Proses dan makna (perspektif subjek) lebih ditonjolkan dalam penelitian kualitatif. Landasan teori dimanfaatkan sebagai pemandu agar fokus penelitian sesuai dengan fakta dilapangan. Selain itu landasan teori juga bermanfaat untuk memberikan gambaran umum tentang latar penelitian dan sebagai bahan pembahasan hasil penelitian. Data yang terkumpul dipelajari sebagai satu kesatuan yang tujuannya adalah untuk mengembangkan pengetahuan yang mendalam mengenai objek yang diteliti. 


\section{Bagan 1 Gambaran Rancangan Penelitian}

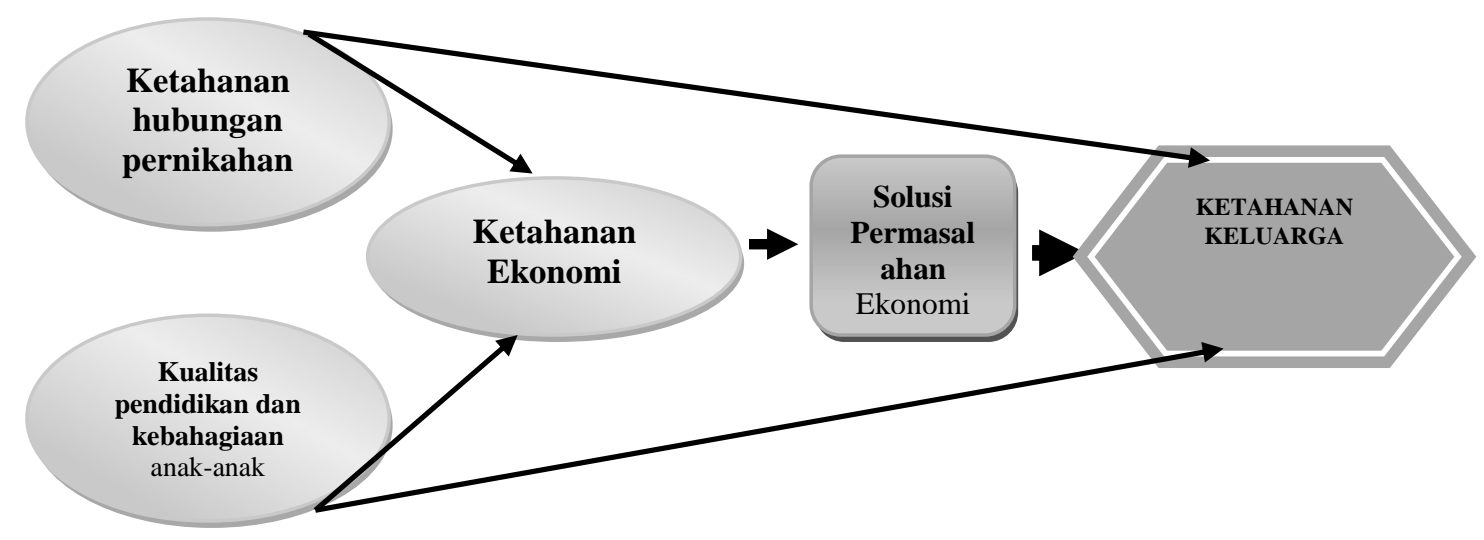

Penelitian ini diiliustrasikan pada bagan di atas dengan beberapa penjelasan, pertama adalah menganalisis ketahanan hubungan pernikahan pada pasangan yang bekerja keluar negeri. Kedua adalah, menganalisis kualitas pendidikan dan kebahagiaan anak yang ditinggalkan orang tuanya bekerja diluar negeri, baik hanya ayah, hanya ibu atau kedua-duanya. Ketiga, menganalisis ketahanan ekonomi sebagai dampak turunan dari ketahanan hubungan dan tidak terpisahkan dari kualitas pendidikan dan kebahagiaan anak, dari analisis seluruh permasalahan, peneliti akan mencoba menemukan solusi efektif sebagai alternatif jalan keluar permasalahan ekonomi tanpa harus bekerja keluar negeri. Tingkat Ketahanan keluarga adalah output atau kondisi akhir keluarga yang dihasilkan dari 4 proses yang telah dilalui di atas.

Sebagai teknik pengumpulan dan analisis / pengolahan data, alat ukur atau instrument yang digunakan untuk mengungkap penelitian ini adalah wawancara dan observasi. Menurut Moleong (2005), berdasarkan keterlibatan pengamat dalam kegiatan orang-orang yang diamati, observasi dapat dibedakan menjadi: a. Observasi partisipan b. Observasi non partisipan Dalam pengamatan ini peneliti menggunakan bentuk observasi non partisipan dimana peneliti hanya mengamati tingkah laku subjek tanpa ikut aktif dalam kegiatan subjek, karena peneliti hanya sebagai pengamat. Melalui metode observasi, peneliti ingin mengetahui gambaran yang lebih jelas mengenai situasi atau perilaku dari subjek/informan.

\section{HASIL}

Kalirejo adalah sebuah desa di wilayah Kecamatan Kalipare, Kabupaten Malang, Provinsi Jawa Timur. Sebutan lain dari desa ini adalah Singkil. Terletak disebelah selatan sungai Brantas. Berbatasan langsung dengan wilayah kabupaten Malang. Mata pencaharian penduduknya adalah bertani dan buruh lepas. Namun banyak dari generasi muda yang sudah lulus sekolah atau kuliah, mereka merantau ke luar daerah, seperti Surabaya, Jakarta, Kalimantan Timur (Balikpapan, Samarinda), dll., dan banyak di antara mereka yang telah berhasil. Bahkan ada yang menempuh penididikan sampai ke luar negeri. Pada musim kemarau wilayah selatan desa ini (Darungan) mengalami kesulitan air. Sekarang sudah ada penyaluran air bersih yang dikelola secara swadaya masyarakat, tetapi 
hanya terbatas untuk wilayah Kidul Gunung dan Lor Gunung. Di desa ini ada beberapa peninggalan bersejarah dari zaman pemerintahan Belanda, seperti Pabrik Gamping, Pertambangan batubara yang terletak di sekitar sungai perbatansan antara Kabupaten Malang dan Kabupaten Malang.

Tabel 1 Ketahanan Hubungan Pernikahan antara Pasangan TKI asal Desa Kalirejo Kecamatan Kalipare Kabupaten Malang

\begin{tabular}{|c|c|c|c|c|c|c|c|c|c|c|}
\hline No & \multicolumn{2}{|c|}{$\begin{array}{c}\text { Nama Istri (I) / } \\
\text { Pendidikan }\end{array}$} & \multicolumn{2}{|c|}{$\begin{array}{c}\text { Nama Suami (S) / } \\
\text { Pendidikan }\end{array}$} & \multirow{2}{*}{$\begin{array}{c}\text { Yang } \\
\text { Jadi } \\
\text { TKI } \\
\text { I }\end{array}$} & \multirow{2}{*}{$\begin{array}{c}\text { Negara } \\
\text { Tujuan } \\
\text { Hongkong }\end{array}$} & \multirow{2}{*}{$\begin{array}{c}\text { Cerai } \\
\frac{\sqrt{ }}{}\end{array}$} & \multirow[t]{2}{*}{$\begin{array}{l}\text { Tidak } \\
\text { Cerai }\end{array}$} & \multirow{2}{*}{$\begin{array}{c}\text { Jumlah } \\
\text { Anak } \\
1\end{array}$} & \multirow{2}{*}{$\begin{array}{r}\text { Usia } \\
\text { saat } \\
\text { Menik } \\
\text { ah (Th) } \\
18 / 20\end{array}$} \\
\hline 1 & Kristin & SMP & Eko & SMA & & & & & & \\
\hline 2 & Wulan & D3 & Irfan & D2 & S & Taiwan & & $\sqrt{ }$ & 1 & $20 / 26$ \\
\hline 3 & Lestari & SD & Sumidi & SD & I & Hongkong & $\sqrt{ }$ & & 2 & $12 / 20$ \\
\hline 4 & Helly & SMA & $\begin{array}{l}\text { Frangk } \\
\text { y }\end{array}$ & SMA & S,I & $\begin{array}{l}\text { Hongkong } \\
\text { Taiwan }\end{array}$ & & $\sqrt{ }$ & - & $31 / 35$ \\
\hline 5 & Ruliyah & SMP & Rateno & SD & I & Hongkong & $\sqrt{ }$ & & 1 & $17 / 18$ \\
\hline 6 & Mimin & SMP & Sarni & SD & I & Hongkong & $\sqrt{ }$ & & - & $23 / 25$ \\
\hline 7 & Santi & SMA & Jemi & SMA & I & Hongkong & $\sqrt{ }$ & & 1 & $20 / 23$ \\
\hline 8 & Sulis & SMP & $\begin{array}{l}\text { Wardoy } \\
\text { o }\end{array}$ & SMP & I & Hongkong & $\sqrt{ }$ & & 1 & $19 / 19$ \\
\hline 9 & Sulastri & SMP & Narko & SD & I & Hongkong & $\sqrt{ }$ & & 2 & $18 / 20$ \\
\hline 10 & Umi & SMA & Anwar & SLTP & S,I & $\begin{array}{l}\text { Malaysia, } \\
\text { Malaysia }\end{array}$ & & $\sqrt{ }$ & 2 & $26 / 29$ \\
\hline
\end{tabular}

\section{PEMBAHASAN}

\section{Ketahanan Hubungan Pernikahan}

Indikator yang dijadikan ukuran ketahanan hubungan pernikahan bagi pasangan TKI dalam penelitian ini adalah, apakah pasangan mampu mempertahankan ikatan perkawinan atau tidak. Keluarga yang harmonis menurut (chapman, 2000. Dalam Puspitawati 2013) memiliki pola kehipan sehari-hari dengan adanya 1) Sikap melayani sebagai tanda kemuliaan, (2) Keakraban antara suami-istri menuju kualitas perkawinan yang baik, (3) Orangtua yang mengajar dan melatih anaknya dengan penuh tantangan kreatif, pelatihan yang konsisten dan mengembangkan ketrampilan, (4) Suami-istri yang menjadi pemimpin dengan penuh kasih dan (5) Anak-anak yang mentaati dan menghormati orangtuanya. Dari tabel hasil, diketahui bahwa jumlah TKI yang bercerai lebih banyak dari pada yang tidak. Dari sampling yang diambil, $70 \%$ bercerai dan $30 \%$ bertahan. Jumlah perceraian inipun rawan untuk mengalami peningkatan. Dari data tersebut peneliti menyimpulkan bahwa ketahanan hubungan pernikahan tidak dalam kondisi baik. Berbeda dengan Penelitian terdahulu yang membahas soal Perilaku Sosial Keluarga Tenaga Kerja Indonesia, yang hanya memfokuskan penelitian pada keluarga Tenaga Kerja Indonesia yang bercerai, sedangkan pada penelitian ini berusaha untuk menyimpulkan apakah dengan pergi keluar negeri sebagai Tenaga Kerja Indonesia menyebabkan ketahanan keluarga akan rapuh (tidak dalam kondisi baik), sehingga akan mengakibatkan banyak dampak negatif yang salah satunya adalah perceraian. Dari perbedaan fokus penelitian tersebut, tentu 
menghasilkan data penelitian yang berbeda pula, misalnya dalam penelitian ini bisa ditunjukkan soal pola perilaku keluarga Tenaga Kerja Indonesia yang tidak bercerai, sedangkan pada penelitian sebelumnya hanya membahas soal perilaku keluarga Tenaga Kerja Indonesia yang bercerai.

\section{Kualitas Pendidikan dan Kebahagiaan Anak}

Penelitian dengan judul "Pengaruh Tekanan Ekonomi Dan Kualitas Perkawinan Terhadap Pengasuhan Anak" yang dilakukan oleh Abas (2007) menunjukkan faktor-faktor yang mempengaruhi pengasuhan anak adalah tekanan ekonomi keluarga dan kualitas perkawinan, dari hasil penelitian tersebut, lebih lanjut dijelaskan ternyata kualitas perkawinan memiliki pengaruh yang signifikan terhadap pola pengasuhan anak, sedangkan faktor ekonomi tidak memiliki pengaruh yang signifikan. Data hasil wawancara dan pengamatan peneliti secara langsung dilapangan, orang tua yang menjadi TKI diluar negeri sebenarnya sangat memikirkan kebutuhan anak-anaknya yang berada di rumah. Baik kebutuhan hidup sehari-hari maupun kebutuhan biaya sekolah. ada anak yang kualitas pendidikannya menunjukkan harapan untuk terus meningkat karena dirumah bersama ibunya dan dibimbing dengan baik, dan ada yang dirawat dan dibimbing hanya oleh kakek dan neneknya akan tetapi juga menunjukkan harapan akan kemajuan prestasinya di masa akan datang, hal ini terlihat dari keseriusan kedua orang tuanya yang berada di luar negeri dan mengirimkan uang dalam jumlah besar setiap bulannya. Hal ini didukung oleh nenek dan kakeknya yang dapat mengelola keuangan dengan baik untuk keperluan anak-anak yang ditinggalkan orang tuanya. Kebahagiaan dan kesejahteraan anakpun terjamin

Anak dari keluarga TKI lainnya, terlihat sangat kurang dalam hal prestasi dan kebahagiaan. Hal ini dapat dilihat dari cara bergaul, sikap, prestasi di sekolah dan pekerjaan yang dijalani. Bahkan ada anak-anak dari pasangan TKI yang sempat menggelandang menjadi anak jalanan, ada pula anak lainnya yang bekerja sebagai makelar di lokalisasi. Dari sikap anak-anak TKI yang damati oleh peneliti di lapangan, peneliti menemukan kecenderungan mereka yang tidak diasuh oleh orang tuanya sendiri terutama oleh ibu, dan mereka yang memiliki orang tua TKI yang bercerai, cenderung memiliki sikap yang kasar dan temperamental. Hal ini kemungkinan disebabkan oleh pola pengasuhan nenek dan kakeknya yang selalu menuruti apapun kemauan dari sang anak. sehingga ketika suatu ketika permintaannya tidak dituruti anak tersebut akan merasa kecewa lebih dalam. Juga perilaku anak yang demikian, sekaligus mencerminkan bentuk protes anak terhadap kondisi pernikahan kedua orang tuanya yang berantakan, sehingga membuat anak terbawa dalam tekanan dan depresi akibat hilangnya harapan untuk memiliki orang tua yang utuh. Dengan demikian kebahagiaan anak-anak seperti ini bisa dikatakan sangat kurang. Dari 10 sampel keluarga yang diambil 6 diantaranya berada di titik rawan, yaitu tidak berprestasi dan cenderung tidak terarah. Sedangkan 2 diantaranya memiliki harapan untuk terus berkembang secara psikis dan intelektual dan mengalami kehidupan yang bahagia.

\section{Ketahanan Ekonomi Keluarga}

Indikator ketahanan ekonomi keluarga dalam penelitian ini adalah gaya hidup dan kelayakan sandang, pangan, dan papan. Simanjuntak (2010) mengemukakan, secara umum ukuran kesejahteraan diklasifikasikan menjadi dua 
kategori, yakni objektif dan subjektif. Kategori pertama mengukur kesejahteraan melalui fakta-fakta tertentu yang dapat diamati seperti ekonomi, sosial dan statistic lingkungan. Kesejahteraan diukur secara tidak langsung menggunakan ukuran ordinal. Gaya hidup sebagian besar TKI mengalami perubahan yang drastis. Meskipun tidak semuanya, akan tetapi sebagian besar mereka yang sebelumnya bergaya biasa-biasa saja berusaha untuk menjadi perfect setelah mengenal kehidupan di luar negeri. Sikap ini diawali ketika mereka masih berada di luar negeri hingga pulang ke kampung halaman. Salah satu dampak perubahan gaya hidup ini adalah adanya perceraian dengan suami atau istrinya. Mereka yang belum terbiasa mengenal banyak hal di dunia luar, setelah bertemu banyak orang, bergaul dengan bermacam-macam orang dan mulai bercara hidup seperti orangorang yang tinggal di luar negeri, akan merasakan ketimpangan besar ketika mereka kembali pada pasangan masing-masing yang kehidupannya masih monoton, tidak ada perubahan sama sekali. Perlahan mereka akan menemukan bahwa pasangannya tidak memiliki criteria sempurna seperti orang-orang yang mereka temui di luar negeri. Ditambah lagi apabila pasangannya dirumah, terutama suami memiliki penghasilan yang lebih kecil, maka mereka akan menganggap suaminya tidak berguna dan hanya menjadi beban. Belum lagi suami yang malah melakukan tindakan-tindakan negative selama istrinya berada di luar negeri, hal ini tentu lebih mempercepat istri yang menjadi TKI memutuskan untuk bercerai.

Tidak semua TKI yang pergi keluar negeri dapat memberikan kelayakan sandang, pangan, dan papan yang mewah untuk keluarganya. Hamper serupa dengan hasil penelitian yang dilakukan oleh Darmo Lelono (2013) yang membahas soal Perilaku Sosial Keluarga Tenaga Kerja Indonesia, menunjuukan bahwa tidak ada perbedaan kesejahteraan yang cukup mencolok pada keluarga Tenaga Kerja Indonesia, antara sebelum pergi keluar negeri menjadi TKI dengan setelah menjadi TKI hingga pulang ke Tanah Air. Seperti halnya data yang diperoleh peneliti, dalam penelitian Darmo Lelono tersebut, juga menunjukkan bahwa kondisi ini disebabkan oleh karena remitan yang mereka kirimkan setiap bulan habis untuk kebutuhan sehari-hari anak dan keluarga dirumah ditambah biaya pendidikan anak. akan tetapi paling tidak kebutuhan primer telah tercukupi dengan remitan yang dikirimkan setiap bulan tersebut. Berbeda dengan keluarga TKI yang tidak hanya mengandalkan penghasilan dari luar negeri, artinya ada sumber pendapatan tetap lain dari keluarga yang dirumah, maka kelayakan sandang pangan papan bisa mencapai di atas standart.

\section{Solusi}

Solusi yang bisa diberikan untuk para TKI agar tidak menjadikan bekerja ke luar negeri sebagai rutinitas dan satu-satunya tumpuan dalam hidupnya yaitu dengan memberikan gambaran-gambaran peluang usaha yang bisa dilakukan oleh para TKI. Seperti membuat kerajinan, mendirikan UMKM atau membuka toko kelontong yang menyediakan kebutuhan sehari-hari masyarakat. Hal ini dikarenakan peneliti melihat masih terdapat banyak lahan kosong di kawasan dekat pegunungan Desa Kalirejo, maka itu merupakan peluang bagi para TKI untuk memanfaatkan remitan yang mereka kirimkan kerumah untuk membeli tanah dan memulai usaha baru, misalnya peternakan atau pertanian. Selain itu usaha lain yang bisa dilakukan adalah membuka toko yang menyediakan 
kebutuhan pokok sehari-hari masyarakat. Hal ini sesuai dengan pengamatan peneliti, bahwa di kawasan Desa Kalirejo, Kecamatan Kalipare, Kabupaten Malang masih sangat sedikit toko yang menyediakan kebutuhan sehari-hari. Peneliti juga melihat banyak terdapat lahan yang ditanami singkong dan ubi, ini dapat dimanfaatkan TKI untuk membuka usaha kecil menengah berupa pengolahan ketela dan ubi menjadi makanan siap saji misalnya berupa keripik sebagai camilan ringan yang mudah dibuat dan banyak di minati. Kedepan, usaha demikian diharapkan bisa menampung sumber daya manusia setempat sebagai pekerja, sehingga akan mengurangi pengangguran dan ketimpangan ekonomi yang ada.

Peluang usaha kerajinanpun juga terbuka lebar, karena di Desa Kalirejo terdapat banyak bahan-bahan kerajinan seperti pohon bambu dan tanah liat di wilayah lereng pegunungan. Jarak Desa Kalirejo dengan Kecamatan Samben juga dekat, yaitu sekitar 2 kilometer, member peluang kemudahan pemasaran hasil produksi rumahan yang ada di Desa Kalirejo. Ditambah lagi pusat kota Samben terletak sangat strategis karena membentang jalan raya yang digunakan sebagai jalur utama keluar masuk dari Kota Malang dan sebagai jalur alternatif pula untuk menempuh perjalanan ke Pasuruan dan Surabaya.

\section{KESIMPULAN}

Berdasarkan penggalian informasi tentang yang dilakukan, baik dengan wawancara langsung dengan pelaku (TKI), dengan menggunakan informan dan informan kunci, dan pengamatan langsung dilapangan, dan juga pengolahan data yang dilakukan, maka kesimpulan dari penelitian ini adalah, bahwa bekerja di luar negeri sebagai TKI tidak menjamin ketahanan keluarga, baik dari segi materi maupun imateri. Demi menjaga keutuhan rumah tangga dan tercukupinya kebutuhan hidup keluarga, menjadi TKI bukan satu-satunya solusi yang dapat dilakukan.

\section{SARAN}

Saran yang dapat disampaikan dari hasil penelitian ini adalah, agar pasangan menikah yang telah memiliki anak khususnya, mempertimbangkan lebih jauh keputusan untuk bekerja diluar negeri. Selain itu, Pemerintah seyogyanya lebih memaksimalkan program pendidikan dan pemberdayan masyarakat. Dengan pendidikan yang baik, masyarakat tentu memiliki tingkat sumberdaya manusia yang memadai. Mengupayakan terbentuknya UMKM dengan merangkul masyarakat menengah kebawah yang berpotensi menjadi Tenaga Kerja Indonesia di luar negeri lebih maksimal lagi.

\section{DAFTAR RUJUKAN}

Abas, T. 2007. Pengaruh Tekanan Ekonomi Dan Kualitas Perkawinan terhadap Pengasuhan Anak. Invotec, 63.

Handoyo, E. 2013. Sosiologi Politik. Ombak: Yogyakarta

Ihromi. T.O. 2004. Bunga Rampai Sosiologi Keluarga. Jakarta: Yayasan Obor Indonesia

Lelono, D. 2012. Perilaku Sosial Keluarga Tenaga Kerja Indonesia. Kajian Tentang Perceraian Keluarga TKI di Desa Sukorejo Kulon, Kecamatan 
Kalidawir, Kabupaten Tulungagung. Disertasi tidak diterbitkan. Malang: Pascasarjana Universitas Merdeka Malang.

Puspitawati, H. 2013. Ketahanan Dan Kesejahteraan Keluarga. Bogor: Institut Pertanian Bogor.

Rahmat, S.P. 2009. Penelitian Kualitatif. Equilibrium. 5(9): 1-8.

Simanjuntak, M. 2010. Faktor-faktor yang mempengaruhi kesejahteraan keluarga dan prestasi belajar anak pada keluarga penerima Program Keluarga Harapan (PKH). 